\title{
Understanding Sino-Japanese Relations: \\ Proposing a Constructivist Approach in Chinese Studies
}

\author{
Takeshi UEMURA
}

\begin{abstract}
This paper proposes a "Cultural Constructivist" approach as a theoretical framework to capture how China's perceived identity of its significant Other is constituted and evolves through social interactions, and how such identity in turn gives meaning to the PRC's interactions with another state. Upon building a theoretical framework, it will first begin with a literature review and critique on Strategic Culture and Constructivism. It then argues that while both cultural factors and social interactions are important in foreign relations, the two IR streams failed to truly integrate the social and the cultural. The Cultural Constructivist approach is a theoretical framework that synthesizes the two to better understand the role of culture in social interactions among states. Using China as a referent point for analysis, the paper argues that China perceives its significant Other Japan through a culturally unique relationship widely known in the disciplines of anthropology, sociology and cross-cultural psychology as guanxi.
\end{abstract}

\section{Keywords}

China, significant other Japan, Cultural Constructivism, Strategic Culture, Constructivism, guanxi

\section{Introduction}

Rational choice theorists in IR have long premised their research on "rational political behavior." To Realists, all states share a common national interest to meet their security requirements. ${ }^{2}$ Yet, how an individual reacts to a certain stimulus depends not on that person's physical environment but on his subjective

\footnotetext{
${ }^{1}$ Anthony Downs, An Economic Theory of Democracy (New York: Harper \& Row, 1957), pp. 9-10.

${ }^{2}$ Hans Morgenthau. In Defense of the National Interest (New York: Alfred A Knopf, 1951); Kenneth Waltz, Theory of International Politics (New York: McGraw-Hill, 1979).
} 
understanding of the stimulus. Such understandings are shaped within each of our respective cultural setting. Perception is a subjective knowledge and it cannot be independent of cultural context ${ }^{3}$; recent research in cognitive psychology has revealed that Westerners and East Asians perceive the world differently. ${ }^{4}$ Thus, rationality is not a universal and intrinsic human nature, but acquired in each of our cultural settings.

This paper uses China's relationship with Japan as a referent point to argue that culture is an important factor in understanding state's perception of its significant Other, based on which foreign policy is formulated. Beginning with a brief literature review of culture's role in IR with a focus on Strategic Culture and Constructivism, the paper will then integrate the two IR streams to construct a new falsifiable analytical framework used in the following section to describe and explain four research questions: (1) Under what conditions and how do Chinese cultural behavior patterns appear in the PRC's Japan policy? (2) How did Japan interpret these behaviors, and were there any misunderstandings due to cultural differences? (3) How did China interpret Japan's (re)actions? How is Japan's identity constructed? and (4) How did Japan's identity influence China's Japan policy?

\section{Literature Review}

\section{(1) Strategic Culture}

The mainstream IR theories have come under criticism of Strategic Culture, which later developed into three different generations. The first generation initially attempted to explain why different security communities approached strategic affairs differently. For them, strategic culture is a context that "gives meaning to strategic behaviour."

\footnotetext{
${ }^{3}$ Max Weber, "Objectivity in Social Science and Social Policy," in Edward Shils and Henry Finch, eds. and trans., The Methodology of Social Sciences (Glencoe, IL: Free Press, 1949), pp. 49-112.

${ }^{4}$ American Psychological Association, "The Culture Cognition Connection," Monitor on Psychology, pp. 37-2 (2006).

${ }^{5}$ Colin Gray, "Strategic Culture as Context," Review of International Studies, 25 (1999), pp.49-69, p. 51.
} 


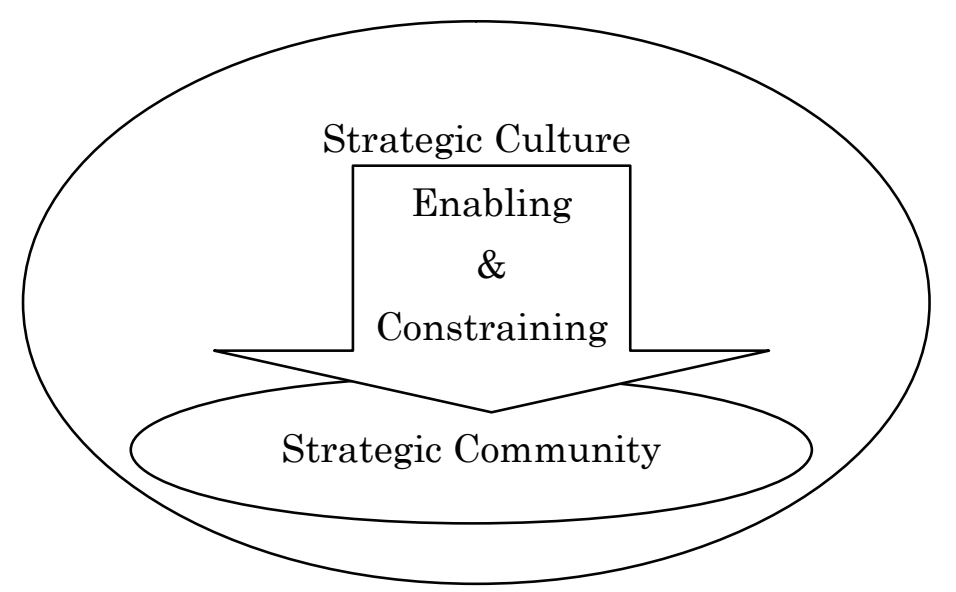

Figure 1: Strategic Culture: First Generation

Source: Author

This generation, however, remains undertheorized and overly deterministic. ${ }^{6}$ Criticizing their tautological explanations, the third generation scholars, such as Ian Johnston, conclude that their basic argument is basically that "everything matters and everything is connected to everything else." "For example, the PRC is often described as a country with a victim mentality, which influences Beijing's foreign policies. ${ }^{8}$ It is often unclear, however, to what extent this history-conscious mentality can speak of China's future. Unsatisfied with the first generation, the third generation focused on the development of falsifiable theories.

The third generation is not without their problems. Questioning Johnson's treatment of strategic culture as a causal factor for strategic behavior, Colin Gray, one of the most prominent first generation scholars, argues that strategic behavior cannot be separated from strategic culture, for such behavior is essentially carried out by encultured people. ${ }^{9}$ In short, the third generation's cause-andeffect approach could be invalid if the independent and dependent variables are inseparable.

\footnotetext{
${ }^{6}$ Edward Lock, "Refining Strategic Culture," Review of International Studies, 36 (2010), pp. 685-708.

${ }^{7}$ Alastair Johnston, "Strategic Cultures Revisited," Review of International Studies, 25 (1999), pp. 519-23.

${ }^{8}$ Shuguang Zhang, "China: Traditional and Revolutionary Heritage," in Ken Booth and Russell Trood, eds., Strategic Cultures in the Asia-Pacific Region (London: Macmillan Press, 1999), p. 35.

${ }^{9}$ Gray (1999), op. cit., p. 135.
} 


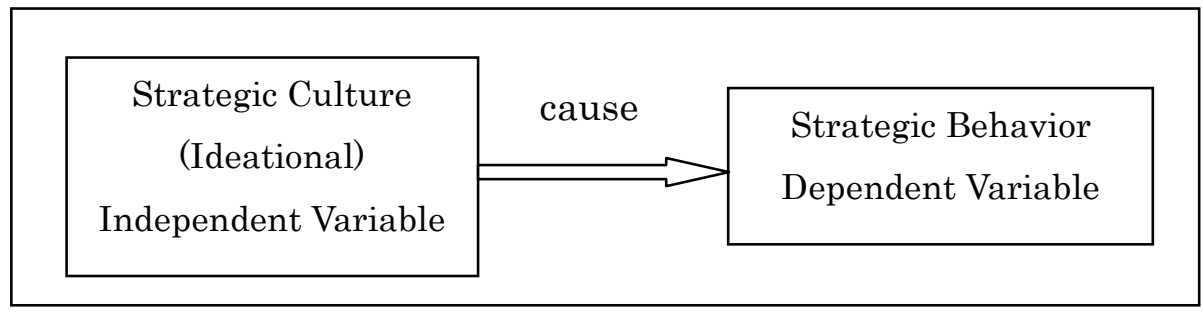

Figure 2: Strategic Culture: Third Generation

Source: Author

Borrowing ideas from Constructivism, the second generation set out to bridge the gaps between the first and third generations. Before discussing the second generation, a brief literature review of Constructivism may be necessary.

\section{(2) Constructivism and the Second Generation of Strategic Culture}

Constructivists contend that ideational factors including culture are constitutive rather than causal. Instead of directly causing state actions, culture sets the basic boundaries for socially viable behavior. ${ }^{10}$

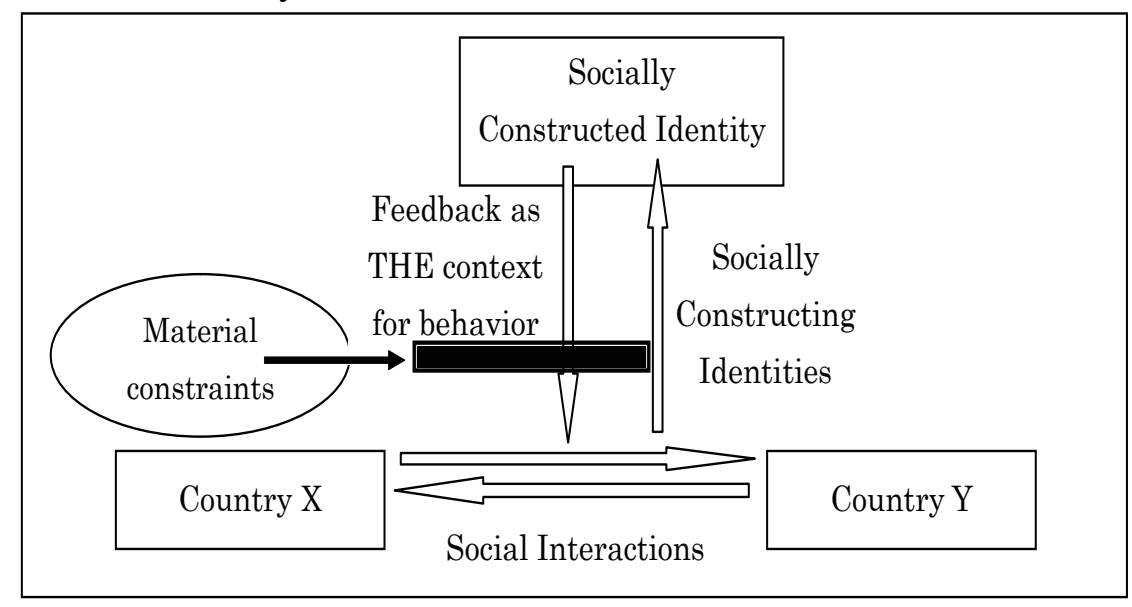

Figure 3: Constructivism

Source: Author

One of the problems in Constructivism, however, is that it pays little attention to culture's role at the unit national level of identity formation. As Colin avers, strategic choices are made "by people and organisations equipped with dominant national (or sub-national) strategic cultural lenses." interpretation of interactions that leads into social construction of identities,

\footnotetext{
${ }^{10}$ Alexander Wendt, "Anarchy is What States Make of It," International Organization, 46-2 (1992), pp.391-425, p. 401.

${ }^{11}$ Gray (1999), op. cit., p. 66.
} 
Constructivists lost the cultural in their analysis of the social.

The development of Constructivism enlightened the second-generation Strategic Culture theorists. They argue that, while influencing strategic practices, strategic culture is also "repeatedly reconstituted through the very practices that it enables and constrains.",

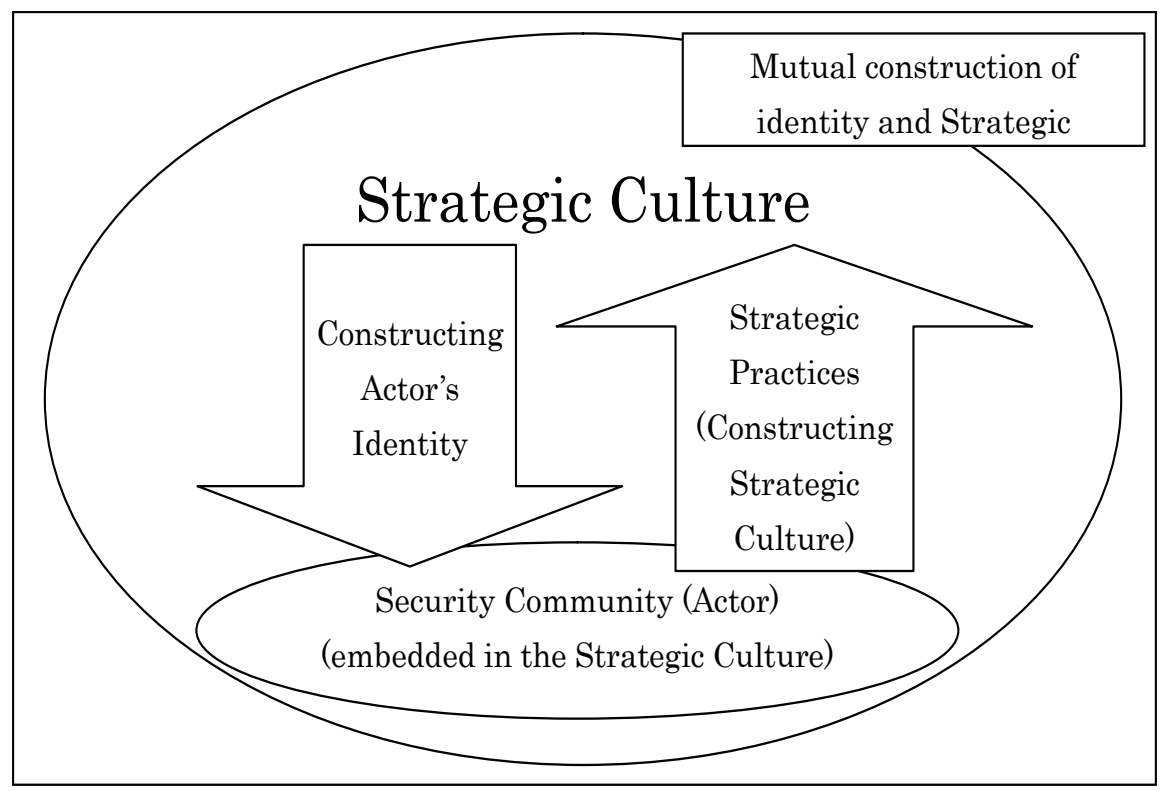

Figure 4: Strategic Culture: Second Generation

Source: Author

However, the Constructivist focus on social interaction became infinitely blurry in the second generation's proposition of mutual constitution of culture and identity. A security community's strategic practice is essentially self-centered in that it does not take other states into consideration. While in Constructivism 'self/other' identity is socially constructed through interactions among actors, the second generation seems to focus on an actor's actions but not on interaction among actors. Mutual construction occurs between strategic practices by the "self" and strategic culture of the "self." The cultural and the social still drift apart.

Lastly and perhaps most importantly, despite the conceptual and analytical differences among the three generations of Strategic Culture and Constructivism, all three implicitly define culture in ideational terms. For the first generation, culture is a set of norms and a context that gives meanings to behavior; ideas in

\footnotetext{
${ }^{12}$ Bradley Klein, Strategic Studies and World Order (Cambridge: Cambridge University Press,
} 1994), p. 37. 
discourse for the second; causal ideas for the third; and social structure consisting of shared ideas for constructivists. However, as Johnston correctly points out, it is extremely difficult to establish a cause-effect relationship (or any type of relationship) between a cultural idea and its possible resulting behavior. To put it more bluntly, we simply cannot get inside the heads of decision makers.

\section{Analytical Framework: Constructing a Cultural Constructivist Approach}

This paper attempts to synthesize and improve the conceptual frameworks of Constructivism and Strategic Culture. Social interaction and (strategic) culture are both significant in constituting states' self/other identities and behaviors. But the social and the cultural cannot function separately from each other, as all social interactions are essentially culturally embedded. China's perceived identity of its significant Other is culturally constructed through their social interactions, which are in turn a reflection of the very identity that China constitutes.

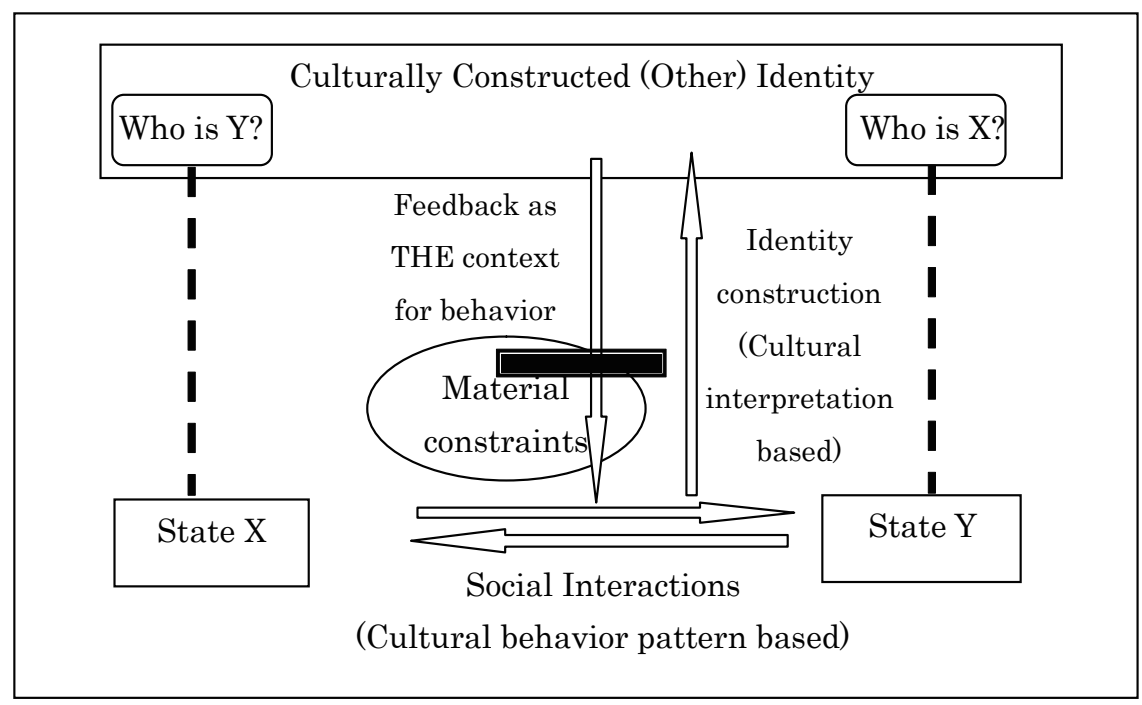

Figure 5: Cultural Constructivist Approach

Source: Author

Figure 5 is a conceptual diagram of the Cultural Constructivist approach proposed in this paper. From State X's point of view, State Y's identity is constructed through the social interactions of the two. Such social interactions must be culturally interpreted to make sense. Suppose for now that State $\mathrm{X}$ is China and State Y Japan. In trying to understand why Japanese prime ministers 
visit Yasukuni Shrine, for instance, China would set such behavior within the Chinese cultural context. Did Japan behave this way to harm China's pride, or to honor its ancestors? The answer depends on how Japan's behavior is interpreted in the context of Chinese culture.

This section lays the theoretical foundation for Cultural Constructivism, which is a synthesis of the cultural and the social, and it begins here with a redefinition of culture. This is a crucial process, because the ideational epistemology of culture as reviewed literatures proved to be extremely difficult to maneuver to formulate a falsifiable theory.

\section{(1) Redefining Culture}

The number of definitions for culture is numerous, but they could be divided into two categories - one focused on the ideational aspect of culture, the other on the behavioral. Defining it in ideational terms, Weber contends that culture shapes our understanding, perception and conception of the world. ${ }^{13}$ Similarly, Hofstede defined culture as "the collective programming of the mind that distinguishes the members of one category of people from another."

At the behavioral end, Sapir argues, "culture should be defined as a series of human activities in a configuration." 15 Culture consists of behavior shared by members of a group and acquired as a result of membership in the group. People behave in remarkably dissimilar ways from one place to another, and "politics everywhere reflects the culture of a time and place."16

Comparing the two sets of definition, I argue that the behavioral one is more suitable for the analysis of state identity and interactions. Focusing on this aspect of culture makes the analysis more observable and therefore more falsifiable. Unlike cultural ideas, cultural behavior patterns do not exist in our heads but actually, physically and observably manifest. Taking this perspective is also intuitive, for interstate relations are essentially the accumulation of state behaviors. Thus, in analyzing China's identity construction and social interactions with its significant Other, we have to first identify the Chinese cultural behavior pattern. How do the Chinese build relationships with others? What cultural behavior patterns are there, and what meanings are construed from state interactions?

\footnotetext{
${ }^{13}$ Weber (1949), op. cit., p. 37.

14 Geert Hofstede, "Diplomats as Cultural Bridge-builders," in Hannah Slavik, ed., Intercultural Communication and Diplomacy (Malta: Diplofoudation, 2004), pp.25-38, p. 26.

${ }^{15}$ Edward Sapir, The Psychology of Culture, Judith Irvine, ed. (The Hague: Mouton De Gruyter, 1993) p. 119

${ }^{16}$ Oliver Woshinsky, Culture and Politics (New Jersey: Prentice Hall, 1995), pp. 1-3.
} 


\section{Guanxi as a Cultural Context for Chinese Perception and Behavior Rationale}

\section{(1) Definitions of Guanxi}

The Chinese build culturally unique relationships widely known as guanxi. Scholarly accounts of guanxi can be traced back to Weber, who saw it as an important element in the unique Chinese normative social order. ${ }^{17}$ Although well researched, guanxi continues to be loosely defined and is generally understood as a relational context in which individuals interact with each other. Different perspectives may define guanxi differently. Lu summarizes that guanxi is a type of social capital and relational asset for sociologists; an adaptation to new environment and culture for behavioral scientists; and informal institutions for institutional economists. ${ }^{18}$ In any case, guanxi remains robust in all types of social practices and discourse of contemporary Chinese society. ${ }^{19}$

Next is a detailed analysis of guanxi, focusing on its two mutually complementary features - 'subjective moral standard' and 'long-term reciprocity.'

\section{(2) Subjective Moral Standard}

First and foremost, guanxi is a particularistic relationship between two persons. In contrast to the West, where an individual's existence is based on the self through introspective processes, the Chinese only exist in their dyad social context within reciprocal relationships with others. ${ }^{20}$ Duties and rights are relational and reciprocal rather than universal. In other words, one's actions can only be correct in a social context of interactions with another in a dyadic relationship. In this sense, all social matters become moral matters. If one side's behavior does not live up to the other's, moral accusation occurs. Perception of someone's identity is virtually a function of a subjectively formed historical experience with that person.

\section{(3) Long-term Reciprocity}

Guanxi is a long-term relationship, formed and sustained through balanced reciprocity. ${ }^{21}$ Favors done for others are often social investments with strong

\footnotetext{
${ }^{17}$ Max Weber, The Religion of China (New York: Free Press, 1968), p. 236.

18 Jiantao Lu, "A Social-network Behavioural Approach to Overseas Chinese and Overseas Non-Chinese Investments in China," Tijdschrift voor Economische en Sociale Geografle, 103-4 (2012), pp.426-42, pp. 434-437.

19 Mayfair Yang, "The Resilience of Guanxi and Its New Developments," The China Quarterly, 170 (2002), pp.459-76.

${ }^{20}$ Lung-kee Sun, Zhongguo wenhua de shenceng jiegou (Guilin: Guangxi Normal University Press, 2012), p. 12.

${ }^{21}$ Wilfried Bolewski and Candy Rietig, "The Cultural Impact on China's New Diplomacy,"
} 
expectations for handsome returns. The norm of reciprocity is guided by an "informal and unwritten code of trust, forbearance, reciprocity and equity." Failure to return favors is blame-worthy, leading to serious damage of one's social standing. Such guanxi must be long-term oriented, as both parties see future values in putting resources to maintain guanxi for long-term benefits, even sometimes at the expense of short-term sacrifices. The rules of equity and reciprocity might also apply to the industrial West, but the emphasis is essentially placed upon isolated individuals "socialized to make rational decisions on the basis of self-interest in most exchange situations." 22

\section{(4) Behavior Patterns}

These two characteristics of guanxi maintain significant implications for Chinese cultural behavior patterns. The Chinese endeavor to maintain moral correctness is manifested in daily socialization such as drinking, eating and gifting. To avoid accidental failures to reciprocate, it is not uncommon for Chinese people to keep detailed lists of favor exchanges. ${ }^{23}$ Thus, subjective moral standard presupposes reciprocation. The pursuit of moral correctness is at the core of Chinese social life.

On the other hand, the emphasis on long-term reciprocity implies that equity in a single round of negotiation is not as important. Fairness and moral obligations are to be fulfilled along the evolvement of guanxi. In a long-term oriented guanxi, the Chinese tend to have a more holistic perspective and place individual events and issues in historical contexts. Particularly at the beginning of guanxi, Chinese are said to be flexible and hospitable in order to gain moral superiority, which might be utilized in the next round of negotiation. ${ }^{24}$

Such guanxi is inherently unstable, for its subjective nature defies objective cost and benefit analysis. Since even the seemingly irrelevant actions could be relevant for a healthy guanxi, it is unavoidable that players lose track of who owes whom. When the indebted continuously fails to live up to the other's expectation for moral conducts, be it out of intention or ignorance, guanxi will eventually collapse with moral accusations ensuing from the unsatisfied side.

\section{(5) Hypothesis and Analytical Methodology}

Guanxi is a cultural framework within which Chinese perception and behavior are constructed. This paper aims to adapt it to the construction of an analytical framework to observe China's perception of and relationship with its significant

The Whitehead Journal of Diplomacy and International Relations, 9-2 (2008), pp.83-96, p. 86.

22 David Messick and Karen Cook, Equity Theory (New York: Praeger, 1983).

23 Yunxiang Yan, "The Culture of Guanxi in a North China Village," The China Journal, 35 (1996), pp.1-25.

24 Bolewski and Rietig, op. cit., p. 87. 
Other Japan.

I hypothesize that in a guanxi of amity, the Chinese would go out of their way to show generosity and friendship while downplaying conflicts. Here, a strong positive inertia would prevail and prevent conflicts from rising to the surface. While this positive inertia might sustain guanxi, it may also disguise conflicts and complicate policy adjustments that are necessary for a sound relationship. Unaware of China's genuine perception, Japan might continue its behavior as the countries' damaged relationship fails to be expeditiously repaired.

Conversely, once the perception turns to a one of enmity, amity may suddenly and bitterly with tremendous negative inertia that sustains hostility. This may hinder China from a purely cost- and benefit-oriented calculation and policymaking for an extended period of time.

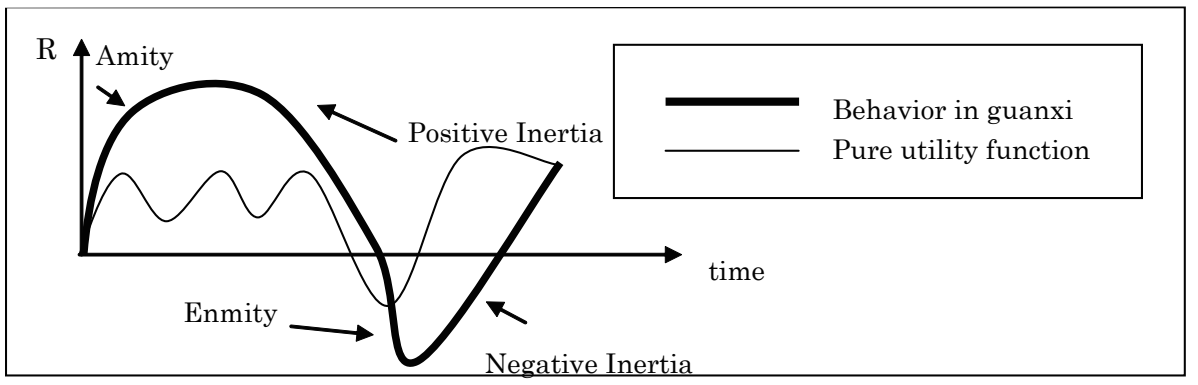

Figure 6: Behavior Pattern in Guanxi

Source: Author

There might be questions regarding the validity of using guanxi, a social concept usually ascribed to individuals, to analyze state political phenomena. However, state is essentially inseparable from its society, in the sense that the former is constituted by norms and rules of the latter. If state and society are linked presupposes each other, then it makes sense to consider social concepts in order to know the state, and vice versa. The following section describes China's identity formation of Japan.

\section{Sino-Japanese Guanxi}

China's Japan policy has received much attention from scholars and professional diplomats alike, with the predominant portion of the literature elaborating on political, economic and historical variables. Emphasizing the role of power and international structure in China's foreign policy, Realists might argue that it was strategically necessary that the PRC normalize with Japan at the beginning of the 
1970s in order to improve its national security vis-à-vis the former Soviet Union. ${ }^{25}$ However, as will be shown in detail later in this section, with a closer look at the bargaining positions of the two in 1972, we will find that Realism cannot rationalize China's series of concessions, including its decision to waive its claim for war reparations.

In addition, Realism simply cannot tell us why China has remained so "cold" and hostile toward Japan since the 1980s, as many Sino-Japanese relation experts and the general public would characterize. Today, the U.S. has by far the strongest military power in the western Pacific and, as Christensen points out, Realists may expect China to welcome Japan's rise as a regional power as a counterweight to American hegemony. However, Chinese analysts do not share the general view held by many Japan experts throughout the West that Japan is unlikely to pursue its military power in earnest in the 21 st century. ${ }^{26}$ The fact that China fears a powerful Japan means that the international balance of power alone is insufficient for telling which nation poses a greater threat to China. National perceptions and historical legacies do matter. China's visceral distrust of Japan exacerbates the security dilemma in their relations. ${ }^{27}$

Neither can Liberal Institutionalists help us understand China's behavior toward Japan. China's trade with Japan surpasses its trade with any other countries in the region by far, except for the U.S. Japan is also the most generous ODA donor for China, providing a total of $¥ 3,133$ billion in loans, $¥ 145.7$ billion in grant aid and $¥ 144.6$ billion in technical cooperation between 1979 and 2005 . $^{28}$ But as exchange of goods, money and people boomed between the two, mutual perception deteriorated instead of making improvements. China did not hesitate to harshly criticize Japan over history related issuvementses during this period. Economist studies show that, today, these two East Asian giants have much to gain from their economic interdependence. ${ }^{29}$ The two countries have too much to lose by blaming each other for historical issues, and their behavior rationale must lie somewhere else than economic interests.

The Constructivist argument that Japan's identity as China's potential enemy took shape as a result of social interaction between the two ignores the fact that

\footnotetext{
${ }^{25}$ For example: Minoru Okada, Nitchu Kankei to ODA [Sino-Japan Relations and ODA] (Tokyo: Nihon Kyoho Sha, 2008).

${ }^{26}$ Peter Katzenstein, The Culture of National Security (New York: Columbia University Press, 1996).

${ }^{27}$ Thomas Christensen, "China, the U.S.-Japan Alliance, and the Security Dilemma in East Asia," International Security, 23-4 (1999), pp. 49-80.

${ }^{28}$ Reinhard Drifte, “The End of Japan's ODA Yen Loan Programme," Japan Aktuell, 16-1 (2008), pp.3-15, p. 3.

${ }^{29}$ Claes G. Alvstam, Patrick Ström and Naoyuki Yoshino, "On the Economic Interdependence between China and Japan," Asia Pacific Viewpoint, 50-2 (2009), pp.198-214, p. 198.
} 
the same set of social interaction could be interpreted differently in different cultures. A long period of military conflict from the end of the nineteenth century is often used as a referent point for the emergence and subsequent persistence of China's Japan image. One of the recent Constructivist approaches was developed by Gries, who traced how China's perception of Japan's identity is historically formed. ${ }^{30}$ But this claim conveniently ignores the honeymooning decade of SinoJapanese relations in the 1970s. Unlike what Constructivists argued, China's image of Japan has not remained static but has undergone a series of changes since the early 1970s, as this section will show. While it is important to capture China's perceptual persistence, it is more meaningful to understand the mechanism of how perception is formed, sustained and changed; that perception cannot be understood without knowing China's cultural behavior patterns.

The research goal of this paper is to describe how China has culturally formed and changed Japan's identity within the guanxi framework. The 1972 rapprochement began with a fleeting amity between the two capitals. To show its moral magnanimity and gain the upper hand in guanxi, Beijing unilaterally forwent its claim for war reparations without any tangible short-term benefits in return. For a decade, positive inertia sustained the amity of guanxi while downplaying outstanding bilateral issues. However, China's perception of Japan changed dramatically from the mid-1980s as Beijing saw Japan being delinquent in its moral obligation. Enmity contained tremendous negative inertia that set the basic undertone of Beijing's Japan policy for years to come. The paper concludes with answers to four questions: (1) Under what conditions and in what way do Chinese cultural behavior patterns appear in the PRC's Japan policy? (2) How does Japan interpret these behaviors, and are there any misunderstandings due to cultural differences? (3) How does China interpret Japan's (re)actions? How is Japan's identity constructed? and (4) How does Japan's identity influence China's Japan policy?

(1) Toward Moral Superiority in a Guanxi of Amity: 1972-1982

In its new guanxi with Japan, China tried to maintain a superior moral position. For instance, a two-thousand-year Sino-Japanese friendship was frequently emphasized not only for its own sake, but also to remind Japan of its cultural indebtedness to China. ${ }^{31}$ In order to morally lock Japan's future behavior, China insisted to add the following part to the 1972 Communiqué. That is: "The Japanese side is keenly conscious of the responsibility for the serious damage that

\footnotetext{
${ }^{30}$ Peter Gries, China's New Nationalism (Berkeley: University of California Press, 2004).

${ }^{31}$ Arif Dirlik, "Past Experience, If Not Forgotten, is a Guide to the Future," in Miyoshi Masao and H.D. Harootunian, eds., Japan in the World (Durham: Duke University Press, 1993), p. 71.
} 
Japan caused in the past to the Chinese people through war, and deeply reproaches itself." 32 Deep reproach is within the range of moral reflection rather than that law. ${ }^{33}$ It is significant to note that China was not very meticulous about its legal rights (such as demands for war reparations), but was very much so regarding its moral position. It is rare to have a moral issue written in a state-to-state legal agreement and China's insistence to do so reflects its cultural behavior pattern.

A misunderstanding already existed from the beginning. The Chinese side was most concerned with the history issue, which was a fundamental moral principle underlying China's new guanxi with Japan. Japan had to forever accept China's version of the past and regret what it did to China. While the Chinese never meant to forgive and forget Japanese brutality, the Japanese took the face value of the Chinese appeal of "forsak[ing] lesser differences in order to achieve big agreement." Not many Japanese China experts worried at the time that such a misunderstanding would create problems in the future.

The war reparations issue vividly reflects China's cultural behavior pattern in guanxi. The PRC announced that it had no intention to claim for war reparation from the Japanese in 1955, long before the Soviet threat overshaws its strategic calculations. ${ }^{34}$ To begin with, the issue had once been settled between Japan and Taiwan in the Sino-Japanese Peace Treaty of 1952, in which Taipei was forced to voluntarily abandon its claim for reparations due to the extremely disadvantaged international environment it faced as the Cold War started to unfold. ${ }^{35}$ But the PRC's negotiation position vis-à-vis Japan in 1972 was much better than that of Taiwan in 1952, therefore leaves us to wonder why Beijing had to abandon its right before the negotiation even started.

For Tokyo, a quick normalization with Beijing was rational from the perspectives of both the international environment it faced immediately after the Nixon Shock and domestic politics that strongly favored Japan to normalize as soon as possible. ${ }^{36}$ Because Tokyo had been constrained by the Cold War structure since the early 1950s, it was unable to make any unilateral moves with Beijing despite its sentiments toward the mainland. The U.S. secret diplomacy with the

\footnotetext{
${ }^{32}$ MOFA, Joint Communique of the Government of Japan and the Government of the People's Republic of China (September 29, 1972), at http://www.mofa.go.jp/region/asia-paci/china/ joint72.html (searched date: November 2010)

${ }^{33}$ Yoshimi Takeuchi, Takeuchi Yoshimi zenshu vol.11 (Collected Works of Takeuchi Yoshimi vol.11) (Tokyo: Chikuma Shobō, 1981), p. 394.

${ }^{34}$ Ji'nian Zhou Enlai Chuban Faxing Weiyuanhui [Publishing committee in memory of Zhou Enlai], Ribenren xinmuzhong de Zhou Enlai [Zhou Enlai in the eyes of the Japanese] (Beijing: Zhonggong zhongyang dangxiao chuban, 1991), p.44.

${ }^{35}$ Yanjun Yin, Chunichi sensō baishō mondai (Tokyo: Ochanomizu Shobō, 1996), pp. 255-305

${ }^{36}$ Ming Wan, Sino-Japanese Relations (Stanford, CA: Stanford University Press, 2006), p. 101 .
} 
PRC cast tremendous repercussions for the Japanese when it came to light in July 1971. In fear of being left behind, even the usually anti-Beijing Premier Sato failingly hurried to approach the PRC. It was urgent that Japan normalize with China in order to avoid being caught in the narrow valley (tanima) of the U.S.Soviet-China triangle. ${ }^{37}$

In addition, Tokyo's China policy also received Washington's endorsement. The Japanese leaders assured Washington that the Sino-Japanese rapprochement would by no means interfere with the U.S.-Japan security relationship, and the disruption of diplomatic ties with Taiwan would not change the island's status in the U.S.-Japan security arrangement. The Honolulu summit meeting between Tanaka and Nixon was to confirm Japan's continuing commitment to these strategic actions. ${ }^{38}$

Rapprochement with China also made political sense domestically. The issue became a focal point in the upcoming Liberal Democratic Party (LDP) leader election. It is true that around the time of the Sino-Japanese rapprochement the political power between pro-Taipei and pro-Beijing LDP members was almost evenly split. ${ }^{39}$ Yet, the power balance of the two rivaling groups within general LDP members did not matter for normalization. Rather, as the China issue was highly controversial, relevant decision-making was concentrated among LDP elites. As the LDP party head election revealed, top decision makers with notable political sway were overwhelmingly in favor of normalization. Among the four party head candidates (Tanaka, Miki, Ohira and Fukuda), only Fukuda was proTaipei. Candidate Tanaka successfully won the election by politicizing the China issue. Promising normalization, he was able to defeat Fukuda by gaining support from the other two pro-Beijing candidates (Miki and Ohira). ${ }^{40}$

For the Tanaka Cabinet and related Foreign Ministry top officials, normalization with Beijing ahead of the U.S. was a matter of their own political advancement. As Tanaka recalls, for many Japanese political leaders, the China issue was more of a domestic than an international matter, and two thirds of domestic problems would be solved if Sino-Japanese relationship get settled. ${ }^{41}$ Tanaka was allegedly willing to pay reparations if the amount was right. Wan's

${ }^{37}$ Hiroshi Shinohara, "Beichū sekkin to nihon no bōei," [Sino-U.S. rapprochement and Japan's defense] Chūō Koron [Central review] (October 1971), p. 149.

${ }^{38}$ Yoshihide Soeya, "Japan's Relations with China," in Vogel et al, eds., The Golden Age (Cambridge: Harvard University Press, 2002), p. 214.

${ }^{39}$ Dahui Huang, Riben duihua zhengce yu guonei zhengzhi [Japan's China policy and its domestic politics] (Beijing: Dangdai shijie, 2006).

${ }^{40}$ Mantaro Furukawa, Nicchū sengo kankei shi [The history of post-War Sino-Japan relations] (Tokyo: Hara Shobō, 1981), pp. 360-62; Wan, op. cit., p. 101.

${ }^{41}$ Kunio Yanagida, Nihon ha moeteiru ka [Is Japan burning?] (Tokyo: Koudansha, 1983), p. 266. 
interview with Japanese diplomats who were involved in decision making during this period confirms that Tanaka was ready to pay $\$ 10$ billion. ${ }^{42}$ Thus, whether China gives up on reparations or not, "with the establishment of the Tanaka Administration, diplomatic normalization was already a foregone conclusion.",43

On the other hand, having brought Nixon to Beijing, China already successfully achieved the goal of forming a de facto strategic alliance with Washington vis-à-vis Moscow. While the alignment with Washington served Beijing's improved national security, as a junior partner of Washington, Tokyo simply did not have the political independence and military might to fundamentally tip the balance of the strategic Washington-Moscow-Beijing triangle. Simply put, at the dawn of Sino-American rapprochement, Beijing was in less of a hurry than Tokyo was to normalize. In addition, Chinese leaders were certainly not oblivious to Tokyo's resentment over America's secret diplomacy and the great momentum within the Japanese government for normalization.

Still, China heeded to Japanese concerns over the U.S.-Japan Security Treaty, the Sato-Nixon Joint Statement and its earlier Peace Treaty with Taiwan by promising not to make them outstanding issues in the negotiation, and not to formally declare the end of war so that the new treaty between the two governments would remain compatible with the 1952 Peace Treaty with Taiwan. On top of these concessions, the Chinese side also compromised its demand for reparations before the negotiation even started. Public sentiment in China was certainly very much against making concessions to the Japanese, but it was not strong enough to stand in the way of Mao's absolute power and charisma. Thus, a brief overview and comparison of the negotiation positions of Japan and China reveals that China probably did not have to waive its right for reparations while conceding so much in other areas. Rather, it was a reflection of a Chinese cultural behavior pattern to morally dominate the guanxi.

The positive inertia of guanxi dominated this period when Beijing made efforts to build a solid relationship while downplaying differences. In spite of showing explicit displeasure over Tanaka's meiwaku speech, Zhou quickly agreed with Ohira that the two countries should end the past history and develop a good relationship. ${ }^{44}$ Neither did the Diaoyu/Senkaku island issue jeopardize the rapprochement. From early 1974 to mid-1975, the two sides signed four bilateral trade agreements, which provided the foundation for further economic relations. The Japanese side was also cooperative. After China's unilateral cancellation of plant contracts with Japan in 1981, Japanese business leaders, out of their

\footnotetext{
${ }^{42}$ Wan, op. cit., p. 379.

${ }^{43}$ Soeya (2002), op. cit., p. 213.

${ }^{44}$ Yomiuri Shimbun (June 23, 2001).
} 
awareness of China's generosity over the reparation issue, exerted much energy to persuade Tokyo to provide ODA. ${ }^{45}$ High-level talks continued and social exchanges flourished after the passing of Mao and Zhou toward the beginning of the 1980s. ${ }^{46}$

In sum, Sino-Japanese guanxi in the 1972-82 decade could be characterized as one of amity. Chinese leaders exerted much effort to reconstruct its Japan identity as a benign neighbor to justify its new diplomatic initiative. China tried to show its generosity in order to gain moral superiority in a new guanxi with Japan.

Since China took guanxi as a one of amity during this period conflicts such as territorial dispute over Diaoyu/Senkaku were put behind as if they did not even exist. This positive inertia would not be sustainable if the moral principle of reciprocity was perceived neglected.

\section{(2) Perception Shift: 1982-1989}

China's perception of Japan started to change from around 1982 when a series of bilateral issues such as the textbook dispute began to rise to the surface. The Chinese side often linked Japan's China policy with China's previous generosity, and accused it of its moral wrongdoings. One such example would be the complaint that although China had generously given up its demand for war reparations, the Japanese Ministry of Education still approved the textbooks refering to invasion of China as entering and leaving. ${ }^{47}$

In 1982, the Chinese made a large deal over the textbook issue, criticizing Japan for the first time since normalization. An intensive diplomatic and media campaign against Japan's textbook revision lasted for six weeks until Tokyo conceded to making corrections. ${ }^{48}$ This controversy served to reveal China's perceived identity of Japan. Without specifically mentioning Japan, Deng Xiaoping indirectly but firmly addressed the issue at the Twelfth Party Congress in September, arguing that China has no tolerance for foreign encroachment on its independence and sovereignty. ${ }^{49}$ The textbook dispute cannot be entirely orchestriated by the Beijing government, as anti-Japanese public meetings and photographic exhibitions mushroomed at different localities of the mainland. ${ }^{50}$ Thus, the textbook debate

${ }^{45}$ Asahi Shimbun (February 14, 1981).

${ }^{46}$ Akihiko Tanaka, Nicchū kankei 1945 - 1990 (Tokyo: Tokyo University Press, 1991), pp. 5354.

47 Tuosheng Zhang, “China’s Relations with Japan,” in Vogel et al., eds., op. cit., pp. 197-198.

${ }^{48}$ Allen Whiting, China Eyes Japan (Berkeley: University of California Press, 1989), pp. 4651.

${ }^{49}$ Xiaoping Deng, Selected Works of Deng Xiaoping, 1975-1982 (Beijing: Foreign Language Press, 1984), p. 396.

${ }^{50}$ Caroline Rose, Interpreting History in Sino-Japanese Relations (New York: Routledge, 1998), p. 137. 
illustrated that a negative perception of Japan prevailed within both Chinese government and Chinese society. As a result of China's hardened stance, the then Japanese Prime Minister Suzuki was humiliated during his visit to China when the Chinese side lectured him on Japan's past aggression and need for compunction. ${ }^{51}$

Scholarly accounts of the dispute vary. Some conclude that China reacted to the issue spontaneously, as it posed a serious threat to Sino-Japanese relations. ${ }^{52}$ Rewriting the history of war was a significant concern that Beijing could not overlook. Others argue that the issue was a manifestation of Chinese domestic politics and/or the international environment. ${ }^{53}$ Whatever strategic rationale lay behind Beijing's decisions to launch the massive media campaign, the Chinese government's policy seems to have resonated with its people's interpretation of Japan. China's cultural interpretation of Japan's conduct set the parameter for its Japan policy.

Ironically, bilateral disputes increased as the amount of ODA increased during the Nakasone Administration. In 1985, Japanese Prime Minister Nakasone made an official visit to Yasukuni Shrine, a Shinto shrine honoring war dead, including class-A war criminals from the Second World War. Protest from China was vehement, and nationalistic students throughout the mainland demonstrated against the visit. On the day of Nakasone's visit, China's official newspaper People's Daily featured stories of anti-Japanese war heroes along with a protest statement by spokesperson of the Ministry of Foreign Affairs. ${ }^{54}$ Japan's role as a menace to China's sovereignty loomed large behind the stories, and nationwide anti-Japanese sentiment fermented.

The Chinese government dealt with the issue calmly, though China's perception of Japan had already started to show changes. In People's Daily, for instance, articles opposing the shrine visit lasted only few days. Except for a short comment by the foreign ministry spokesperson on the $15^{\text {th }}$, the government did not publish any provocative protests. Rather, Japanese opposition parties' objection to the visit was documented, as in addition to references to brutal crimes committed by the Japanese during the Nanjing Massacre and Unit-731 biological warfare. Writers of these news articles seemed very cautious in wordings so that harsh expressions were directed exclusively against Japanese militarists. Heeding to the bilateral relations with Japan, mixed messages were sent out as was in the $16^{\text {th }}$ article, which documented a friendly meeting between the Japanese prime minister and

\footnotetext{
${ }^{51}$ Chalmers Johnson, "The Pattern of Japanese Relations with China," Pacific Affairs, 59-3 (1986), pp.402-28, pp. 419-25.

${ }^{52}$ Furukawa, op. cit.

${ }^{53}$ Rose, op. cit.

${ }^{54}$ People's Daily (August 15, 1985).
} 
China's ambassador. ${ }^{55}$ Judging from China's mixture of criticism and appeasement of Japan, it can be inferred that facing a significant Other who behaves beyond the framework of cultural behavior pattern of itself, China's perception of Japan was in a stage of confusion that denotes neither amity nor enmity.

In the following years, bilateral issues emerged incessantly. The textbook dispute resurfaced and the Japanese government once again succumbed to Beijing's pressure, promising that the disputed portion be reexamined and a revised textbook guideline newly issued. Also, Beijing strongly protested when the Japanese court ruled the ownership of Kokaryo, a student dormitory in Kyoto, to Taipei instead of Beijing. Tokyo explained that its government was in no position to intervene in a court ruling based on the system of separation of power. The issue was intricately related to history and China's sovereignty, as it involved Taiwan which had once been appropriated and made a colony of Japan. Deng Xiaoping bluntly pointed out that Kokaryo was a moral issue. Linking the dispute to China's earlier generosity, he argued that Japan should recognize its deep indebtedness to China, a country that could have but did not demand war reparations at the time of normalization. ${ }^{56}$ These events in the mid-1980s significantly changed China's perception of Japan, and a more worried Beijing criticized Japan's increase in defense spending to only slightly above one percent of its GNP.

Meanwhile, Chinese propaganda further vitiated Japan's image among the general public and cast profound implications for its long-term Japan policy. Harsh verbal expressions and shocking imagery used to describe Japan's atrocities against Chinese citizens during the war flooded the media. ${ }^{57}$ China's Japan experts were also often dissatisfied with Japan's attitude of seeing itself as a victim instead of a victimizer in the war. After Nakasone's Yasukuni visit, an article in People's Daily by a Japan expert noted that there is little self-criticism against Japanese militarism and imperialism. ${ }^{58}$ Meanwhile, mass anti-Japanese demonstrations increased after 1985.

China's concern over Japan's defense capability was also a function of its perceived identity of the neighbor. In his meeting with Japanese Prime Minister Suzuki Zenko in September 1982, Zhao Ziyang no longer mentioned bilateral cooperation against hegemonism. ${ }^{59}$ Further, Nakasone's suggestion in November 1983 to exchange information on Soviet deployment in the Far East received

\footnotetext{
55 People's Daily (August 16,17, 1985).

56 Masashi Ando and Kazuki Kotake, eds., Genten Chūgoku Gendai-shi, Volume 8: Nicchū Kankei [Original sources of modern history of China] (Tokyo: Iwanami Shoten, 1994), p. 269.

57 Whiting, op. cit., p. 51.

58 People's Daily (August 19, 1985).

59 Huan Tian, ed., Zhanhou zhongri guanxi wenxianji, Volume 2: 1971- 95 [Documents of post-War Sino-Japan relations] (Beijing: Zhongguo shehui kexue chubanshe, 1997), p. 384.
} 
no reply from $\mathrm{Hu}$ Yaobang. ${ }^{60}$ Beijing also reversed its initial support for Japan's military buildup. In February 1983, China Foreign Minister Wu Xueqian told the Japanese side that Japan's armed forces should be limited to defense. ${ }^{61}$ Regardless of Japan's reserved defense orientation, ${ }^{62}$ the Chinese media exercised strong caution against the Nakasone cabinet's decision to break the ceiling of one percent of GNP for annual defense spending in $1987 .^{63}$

As Japan's identity deteriorated, economic frictions were also politicized. Beijing was becoming increasingly irritated by the soaring trade deficit with Japan. In July 1985, Gu Mu complained to the Japanese side that the huge deficit would obstruct development of the two countries. ${ }^{64}$ Although the deficit was a complicated phenomenon not necessarily caused by the Japanese side alone, both Chinese elites and the general public seem to have expected Japan to generously support China's economic development. Dissatisfied with the bilateral economic relations, Deng Xiaoping mentioned in June 1987 that Japan should remember its indebtedness to China for not requesting reparations, and offer to help for China's development. ${ }^{65}$ Deng's statements resonated with Chinese citizens who went out on the streets shouting against "Japanese Economic Invasion." ${ }^{\text {"W6 }}$ Whenever a problem arose in Sino-Japanese relations, there was always strong social pressure on Chinese leaders to make Japan concede.

Here, a collectively shared opinion of Japan had already begun to significantly constrain Chinese leaders' Japan policy. He Yinan points out that even the then supreme leader Deng Xiaoping was significantly constrained by domestic social and political pressure to take a strong stance against Japan. ${ }^{67} \mathrm{Hu}$ Yaobang also suffered a political setback after Nakasone's 1985 Yasukuni visit, as he was attacked by conservatives for being too close with Nakasone. ${ }^{68}$

Thus, China's perception of Japan had started to change dramatically since 1982. The new guanxi of friendship with Japan was premised on that Japan repents its past aggression and behave accordingly, as China insisted in the 1972

\footnotetext{
60 Joseph Y.S. Cheng, “China's Japan Policy in the 1980s," International Affairs, 61-1 (1984/85), pp.91-107, p. 96.

61 Tian, op. cit., p. 408.

62 Joseph Keddell, The Politics of Defense in Japan (New York: ME Sharpe, 1993), Chapter 1.

63 Jun Yasuda, "Bōei yosanan 'tai GNP 1\% toppa,'ni taisuru chugoku gawa no han'nou" [China's reaction to the defense budeget over 1\% of GNP] Shin Böei Ronshu [Journal of National Defense] 15 (1) (1987), p. 97.

64 Tanaka (1991), op. cit., pp. 135-37.

65 Kazankai (1998), op. cit., p. 707.

66 Tanaka (1991), op. cit., p. 143.

67 Yinan He, The Search for Reconciliation (New York: Cambridge University Press, 2009), p. 214.

${ }^{68}$ Hidenori Ijiri, "Sino-Japanese Controversy," in Christopher Howe, ed., China and Japan (Oxford: Clarendon Press, 1996), p. 76.
} 
Communiqué. Therefore, Tokyo's policies toward the textbook, Yasukuni and Kokaryo issues appeared to the Chinese that Japan was not seriously repenting its past actions. In the eyes of China, Japan failed to fulfill the moral obligation of guanxi, and the entire foundation of reciprocity and amity started to crumble.

\section{(3) Guanxi of Enmity: 1989-1998}

After a period of reinterpretation of Japan's identity through the bilateral interactions durin the 1982-89 Sino-Japanese guanxi, China came out disappointed by Japan's negligence of its moral obligation. As a result, the memory of Japan's invasion was recalled and negative perception of the neighbor was consolidated in the 1990s. Which part of the past a society chooses to retain as its collective memory depends on its contemporary ideas and preoccupations. ${ }^{69}$ Rather than celebrating a two-thousand-year friendship between these two similar cultures, China chose to recall the traumatic war experience with Japan to symbolize the country's deepest threats and fears.

Although Japan's identity as an enemy was reconstructed under the strong initiative of the CCP in order to divert domestic discontents overseas, it was an identity that fit the social context of China-Japan interaction in the previous decade and so could be accepted by the general public. War experience with Japan may also be deeply planted in Chinese people's memory. However, without the Sino-Japanese quanxi in the preceding 1980s, when the perception of Japan that lacks moral correctness was formed China would not here brought up war memories and critisized Japan so harshly and persistently.

As Chinese state and society continued to articulate this image of Japan, Japan's role, arbitrary in the previous decade, was consolidated as an enemy of China in the 1990s. Japan was repeatedly used as a symbol of China's past humiliation, and national narratives as such became routinized and shared down generations and among state society members. With a strong focus on remembrance of the antiJapanese war, Japan's contemptible identity was shared through songs, films and books, in addition to school education and museums. ${ }^{70}$ In short, China's perception of Japan was institutionalized.

Although the post-Tiananmen years first boded well for Sino-Japanese relations, instead of a genuine amity, Beijing turned to Japan only for instrumental purposes to maneuver through international isolation and access Western countries. Chinese government clearly discouraged any writing against Japan. Regardless of Tokyo's effort to provide military assistance for U.S. operations in the Gulf War and its

\footnotetext{
${ }^{69}$ Maurice Halbwachs, On Collective Memory (University of Chicago Press, 1992), p. 224.

70 Zheng Wang, "National Humiliation, History Education, and the Politics of Historical Memory," International Studies Quarterly, 52 (2008), pp.783-806, p. 799.
} 
five-year defense program buildup that started in 1990, the Chinese government refrained from repeating its previous criticism against the Japanese revival of militarism. ${ }^{71}$ The fact that Beijing first turned to Tokyo but not to Western countries reveals its tacit but firm belief that Japan, due to its moral indebtedness to China in their guanxi, must feel obligated to help China get back on its feet in a time of predicament.

Tokyo responded positively to Beijing's appeasement. When international pressure to place economic sanctions against China was accumulating, the Japanese Prime Minister Uno argued that Japan could not follow the harsh policies of Western countries, for Sino-Japanese relations simply "differ from those of the United States.” Japan thus played a special role in the 1989-1992 period in bringing the PRC back into the international community. It was against this backdrop that Jiang Zemin visited Japan and the Japanese emperor, who in 1992 reciprocated a visit to Beijing for the first time in history. Not only were the Japanese sanctions the most restrained among industrial countries in the Group of Seven, but Tokyo was also the very first to resume full cooperation with China in as early as 1991 .

However, the perception of an evil Japan unheedful of its past aggression had not changed, even though Beijing knew there was much to gain through cooperation with Tokyo. Both countries wished to denuclearize the Korean Peninsula, desired for sea-lane safety in the Pacific Rim, and shared common goals in energy security, environmental protection, counter-terrorism, transnational crime and proliferation of weapons of mass destruction. Yet, once the instrumental value of appeasing Japan disappeared and the negative impacts of Tiananmen started to wane, Beijing resumed its criticism. In the guanxi of enmity, Japan has been perceived as a potential menace that could compromise China's national interests. "[W] hether or not states really are existential threats to each other is in one sense not relevant, since once a logic of enmity gets started states will behave in ways that make them existential threats." 72

In vivid contrast to the 1970s when Beijing cultivated and nurtured friendship with Tokyo, in the 1990s China frequently criticized Japan for its lack of moral compunction over past wrongdoings. The undertone of these criticisms emphasized the "need to admit your mistakes and get back on the right path toward a healthy relationship." Bilateral problems once avoided were now emerging. Beijing became more vigilant toward Tokyo's position over Taiwan, pushing for Japan to adopt a Three-No policy_clearly not included in the 1972

\footnotetext{
${ }^{71}$ Robert Ross, "U.S. Relations with China," in Vogel et al., eds. (2002), op. cit.

${ }^{72}$ Alexander Wendt, Social Theory and International Politics (New York: Cambridge University Press, 1999), p. 236.
} 
Communiqué. ${ }^{73}$ Beijing also explicitly expressed its ingratitude for Tokyo's official development aid. When the Japanese government decided to suspend ODA in August 1995 to put pressure on Beijing's nuclear tests, the Chinese Foreign Ministry issued a lengthy statement, arguing that Japan "should engage in deep introspection of previous war crimes." Li Peng points out that Japan's ODA could never fully compensate for what Japanese militarists had done to the Chinese people in the past. ${ }^{74}$

China's negative perception of Japan could not be concealed in its actual foreign policies. In response to Kim Dae-Jung's commitment to never mention history problems during the Japan-Korean Summit in 1998, the Japanese side agreed to express their "deep remorse and heartfelt apology" for the Korean people in the Japan-Korean Joint Declaration. In contrast to this smooth and considerable improvement of a bilateral relationship, shortly thereafter on a visit to Japan, Chinese President Jiang Zemin demanded the same treatment but refused to make any promises regarding history issues. The Japanese Premier Obuchi did not yield to Chinese pressure and so no such words were added to the SinoJapanese Joint Declaration. ${ }^{75}$ The Declaration also lacked the signatures of the two leaders, and Jiang lashed out at Tokyo's attitude on history in every city he visited in Japan.

Beijing's perception of Japan based on a guanxi of enmity began to trigger backlash from Tokyo. The Tiananmen massacre had already eroded China's moral superiority over Japan, who became less willing to take moral criticism. China's excessive use of the history card had estranged even those Japanese who wished to improve relations with China. For example, the pro-Beijing former Foreign Minister Kono pressured China to sign the Comprehensive Test Ban Treaty in $1995 .^{76}$ As mutual perceptions deteriorated, the Sino-Japanese rivalry simmered over leadership in Asia and territorial disputes in the East China Sea. In addition to China's nuclear tests in the mid-1990s and Beijing's large-scale military exercises in the Taiwan Strait to blackmail Taiwan at the eve of its presidential elections in 1996, the growing rivalry over history-related issues put the Japanese on high alert over the PRC. Beijing's persistent moral accusations pulled its guanxi with Japan into a downward enmity.

\section{Negative Inertia (1998 ?)}

After the 1998 Jiang-Obuchi summit, it became clear to Beijing that its Japan

\footnotetext{
${ }^{73}$ Wan, op. cit., pp. 127-128.

74 Beijing Review (September 18-24, 1995; October 16-22, 1995).

${ }^{75}$ Yomiuri Shimbun (November 27-28, 1998).

${ }^{76}$ Asahi Shimbun (December 20, 1995).
} 
policy had proven counterproductive. Thus, for a short period thereafter China attempted to switch to appeasement. The 1999 Jiang-Obuchi summit produced a bilateral agreement on China's WTO accession, and the Chinese leader refrained from mentioning history during the talk. In 2000, Jiang met a 5,000-member Japanese delegation and emphasized the importance of a good relationship with Japan. Without discussing history, Zhu Rongji visited Japan in October 2000, helping to improve Japan's image of China.

Yet, even now Beijing has not been able to completely pull itself out of guanxi's negative inertia, that confines its Japan policy. History still tops as the most sensitive issue, ahead of Taiwan, Diaoyu/Senkaku disputes, and U.S.-Japan security cooperation. ${ }^{77}$ Through history issues, China concluded that Japan cannot live up to its expectation as a responsible counterpart in their morally reciprocal relationship. The former Chinese Ambassador to Japan, Chen Jian, argued that "Japan did not thoroughly, profoundly and comprehensively reconsider its aggression against China." 78 The former Chinese Foreign Minister Tang Jiaxuan commented that "Japan has never completely abandoned its militarist past in the same way as Germany has with the Nazis. If it were to do so, China and other Asian nations would not have to keep reminding Japan of history so often."79 The Chinese Foreign Minister Li Zhaoxing asked why Japan cannot do what Europeans have done over history issues. ${ }^{80}$

Beijing's emphasis of the history issue as the political foundation of the bilateral relationship seems genuine rather than merely rhetorical. For instance, the argument that China uses history as its diplomatic card only in order to have a better bargain in political and economic areas vis-à-vis Japan cannot be justified, for it cannot explain overseas Chinese criticism against Japan. ${ }^{81}$ If the history issue were indeed a rhetoric that the Chinese employ in order to manipulate, it should be raised more often during disputes than at other times and directed mainly at the Japanese audience. In reality, however, it has been raised in both eventful and tranquil times and targeted mainly at the Chinese audience. He Yinan argues that compared with the propagandistic aim of Beijing's media campaign in the 1960s, China now demands Japan's "sincere contrition and serious reform of history educations." In addition, the scale and spontaneity of anti-Japanese

\footnotetext{
${ }^{77}$ Ministry of Foreign Affairs of the PRC, "Some Sensitive Issues" (May 8, 2002), at http:// www.fmprc.gov.cn/eng/wjb/zzjg/yzs/gjlb/2721/2722/t15974.htm (searched date: November 23, 2010).

${ }^{78}$ Beijing Review ( March 13, 2000).

79 Michael Laris, “An Apology Rooted in Fear,” Washington Post (November 25, 1998).

${ }^{80}$ China News Agency (March 6, 2004).

${ }^{81}$ Daqing Yang, "Nichū ryōkoku no wakai," [Reconciliation of Japan and China] in Funabashi Youichi, ed., Nihon no sensō sekinin wo dou kangaeru ka [How to think about Japan's war responsibility] (Tokyo: Asahi Shimbunsha, 2001), p. 201.
} 
mass demonstrations are too great for all of them to be administered by Beijing. For example, the CCP even takes action to restrain its people from excessive antiJapanese movements on occasion. ${ }^{82}$ It is difficult to imagine that China would sacrifice its long-term relationship with Japan by hounding it about history issues just for the sake of short-term benefits. As Japan's sense of guilt fades and the effectiveness of China's history card decreases, it only makes sense to conclude that the reason China still holds on to the history issue so tenaciously goes beyond diplomatic utility.

The CCP's patriotic campaign has been successful precisely because it resonated with Chinese people's perception of Japan. Among all the external conflicts, the Chinese government and society chose to demonize Japan not only because it was the country that rendered the deepest wound to China's pride, but also because it, in China's eyes, was egregiously attempting to evade war responsibility. To the Chinese, if Japan fails to reciprocate their previous favor, they would have to reclaim their right for compensations. Thus began the war reparations movement by Chinese war victims filing lawsuits in Japanese courts.

China's memory did not fade with time. Taking the Yasukuni dispute, for example, it was counterintuitive to find out that China criticized the Japanese prime minister's visit more harshly in 2001 than in 1985. In July 2001, Chinese Foreign Minister Tang Jiaxuan met with his Japanese counterpart Makiko Tanaka and warned that Koizumi's visit would cause extremely serious political problems for the two countries, because the decision would reflect Japan's lack of commitment to repenting its past. With pungent verbal bombardment, Beijing issued a series of statements and strongly urged Koizumi to cancel the visit. Deputy Foreign Minister Wang Yi said that treatment of the Yasukuni issue had always been a touchstone of Japan's attitude toward its history of aggression. By ignoring the 1972 political principle that the Japanese side would stay keenly aware of the serious damage it did to the Chinese people, Koizumi's decision, Wang claimed, had once again made Asian people lose confidence in Japan. In contrast to the Nakasone visit in 1985, People's Daily covered related issues much more intensively and for a much longer period in $2001 .^{83}$

In comparison with other neighboring countries, even South Korea with its past of annexation as a Japanese territory made an effort to move beyond history after 1998. Although the history issue reemerged in South Korea-Japan relations in early 2005 when Japan's Shimane prefecture designated February $22^{\text {nd }}$ as "Takeshima Day" for a disputed island (Dokdo in Korean), the situation was contained by the Korean government, and Seoul said it would continue mutual

\footnotetext{
${ }^{82} \mathrm{He}$ (2009), op. cit., pp.227-79.

${ }^{83}$ People's Daily (July 25, 28, 30, 31; August 1, 3, 8, 10-27 2001).
} 
visits by leaders. South Korea and China are similar in that both want to maintain a sound economic relationship with Japan. Also, when China harshly criticized Japan over the Yasukuni visit, Southeast Asian nations did not engage in any large-scale intense criticism against Japan. Upon visiting ASEAN countries after Koizumi's Yasukuni visit, the LDP leader Taku Yamazaki noticed that ASEAN officials focused more on economic cooperation with Japan than on history. ${ }^{84}$

In contrast, China and Japan have continued mutual hostility. ${ }^{85}$ A survey in 1999 showed that over half of Chinese people associated Japan with "aggression," "hatred" and "war." 86 A 2004 poll revealed that the primary reason student respondents did not feel close to Japan was that they believed Japan did not repent of its past invasion to China. ${ }^{87}$ In the anti-Japan social climate, it grows increasingly more difficult for Beijing's policy makers to take bold measures toward cooperation, lest their own political positions be undermined.

As China continues to see Japan as a potential foe, China's Japan policy has caused significant repercussions from Japan. In marked contrast to its reactive approach in the 1982-89 period, the Japanese government is becoming more irritated with China's highhandedness and more explicit about its concerns over Chinese nuclear tests, defense spending, missiles, illegal immigration and Chinese ships in the disputed sea areas. ${ }^{88}$ In the social process of interaction, perception of the Other becomes "self-fulfilling prophecy." that perpetuates a perceived identity. That is to say, if a country sees another as its enemy, the other will indeed behave as one. Seen as an enemy, Japan can only assume that assigned role and confront China. As a result, both countries now seem to be trapped in this negative inertia from which neither could pull out unilaterally.

\section{Conclusion}

What was the academic value of the Cultural Constructivist approach and the guanxi framework in Sino-Japanese relations? Or, to put it differently, what did it accomplish that conventional wisdom failed to? Juxtaposing it against Realism, to what extent was China's Japan policy influenced by other powers? Beijing's strategic concern over the two superpowers was certainly not irrelevant.

\footnotetext{
${ }^{84}$ Asahi Shimbun (August 22, 2001), p. 155.

${ }^{85}$ Yoshiki Kobayashi, "Chūgoku ni okeru tainichi kanjō ni kansuru kōsatsu," [Analysis of China's feelings toward Japan] Asian Studies, 54-4 (2008), pp.87-108.

${ }^{86}$ Yomiuri Shimbun (September 30, 1999).

${ }^{87}$ Lifeng Jiang, "Zhongguo minzhong dui riben de buqinjingan xianzhu zengqiang," [The Evident Increase of Chinese Public Feeling of Alienation toward Japan] Japanese Studies, 6 (2004).

${ }^{88}$ Wan, op. cit., p. 134.
} 
But international distribution of power alone is insufficient for us to understand China's threat perception.

A shift in power balance per se does not necessarily entail policy reorientation. Realists may argue that China hardened its position vis-à-vis Japan as it perceived a relative decline of Soviet power after the Reagan Administration issued its aggressive security policy. The rationale is that a weaker Soviet Union meant a decrease in the utility value of Japan as a counterweight. Although Beijing had attempted to garner whatever support was available against Moscow, in reality it is unlikely that Tokyo has ever been on par with the two superpowers in Beijing's strategic calculation. If there was any country China should have balanced as a result of Soviet decline, it was the U.S. As history proves, however, China's perception of the U.S. was immune to its relative power status. Rather, its people's image of the United States steadily improved during the 1980s in tandem with a deteriorating opinion of Japan, declining Soviet threat and toughening U.S. foreign policy.

A similar argument also applies to the United States. A pure balance-ofpower theory would predict that China encourage Japan's military buildup as a counterweight against the U.S. in the unipolar world after the 1990s. As illustrated here, however, this situation is obviously something that China wanted to avoid. Instead of a function of power balance, China's Japan policy only reflects the perceived identity of its neighbor. If the two nations had truly put their past behind them and nurtured friendship, they would have never engaged in a realpolitik game or been influenced by major world powers.

The Cultural Constructivist approach captures the process of such identity construction. Japan's identity as China's significant other has been constructed through guanxi in a bilateral relationship that strongly reflects Chinese cultural behavior pattern. China's generosity in foregoing its demand for war reparations and avoiding disputes with Japan in the initial phase of amity was not out of pure goodwill, but followed a cultural behavior pattern dictated by guanxi in which China assumes the morally dominant position. As time passed without Japan repenting of its past, China's perception of its former friend began to sour in the 1980s and a guanxi of enmity developed that has dominated China's Japan policy since the 1990s. In response to China's Japan policy, Japan's perception of China likewise deteriorated, and the two now sit bogged down in a bilateral structure that benefits neither.

As a summary, the rest of the paper answers the four questions raised at the beginning: (1) Under what conditions and in what way do Chinese cultural behavior patterns appear in the PRC's Japan policy? The existence of guanxi necessitated two conditions: China's moral superiority and expectation of longterm reciprocity. First of all, China forsook its claim for war reparations during 
the normalization negotiation process in exchange for moral superiority over Japan. Granted that China had few material resources economically or politically to impress Japan otherwise, the war reparations issue served as an effective way to dominate the guanxi. Second, moral superiority automatically entails the expectation of reciprocity in the long run. This is where the cultural and the material intertwine. Cultural behavior such as generosity exercised to obtain moral superiority is essentially materially motivated with the goal of longterm gains. There are a few points that make Sino-Japanese guanxi cultural. For the Chinese, moral superiority was more important than tangible shortterm gains. Indeed, there is no evidence to the author's knowledge that Beijing wanted Tokyo's economic support at the point of normalization. Especially when the two countries normalized their relations, China was still in a precarious international environment with military risks and political uncertainties with the two superpowers. Though it was not certain that moral superiority vis-à-vis Japan would yield specific benefits at the beginning, as a risk management tool, it was clear to Chinese leaders that it was a more valuable asset than war reparations. This is the long-term benefit that the Chinese secretly expected.

(2) How did Japan interpret these behaviors? The Japanese side did not seem to fully understand China's intentions. The fact that China's announcement to forsake war reparations came as tremendous shock shows that the Japanese were unaware what lies behind such generous offers. Also, Japan never truly understood China's reaction to its history related policies. While the Chinese seriously meant what they said, and developed mistrust and antagonism against Japan over its treatment of their history, the Japanese tend to regard such criticism as rhetoric for material gains.

(3) How did China interpret Japan's (re)actions? This misunderstanding due to cultural differences significantly hindered effective communication. The Japanese never sounded out China's hidden agenda at the beginning of their normalization. Neither have they been able to appreciate the visceral hatred in Chinese people over Japan's treatment of their history. The initial generosity and following acrimony of the Chinese are essentially two sides of the same coin of guanxi. With Japan failing to live up to China's moral expectation to comply with the Chinese version of the past, and only less likely to do so in the future, its identity in the eyes of China has and will continue to deteriorate falling, prey of an increasingly avid Chinese nationalism.

(4) How did Japan's identity influence China's Japan policy? This point has been focus of much of the paper, and so it should suffice to say that Beijing's Japan policy is a direct reflection of its perceived identity. 


\section{References}

Alvstam, Claes G., Patrick Ström and Naoyuki Yoshino, "On the Economic Interdependence between China and Japan: Challenges and Possibilities," Asia Pacific Viewpoint, 50-2 (2009), pp.198-214.

American Psychological Association, "The Culture Cognition Connection," Monitor on Psychology, 37-2 (2006).

Ando, Masashi and Kazuki Kotake, eds., Genten Chūgoku Gendai-shi, Volume 8: Nicchū Kankei [Original Sources Modern History of China, Volume 8: JapanChina Relations] (Tokyo: Iwanami Shoten, 1994).

Asahi Shimbun (February 14, 1981; December 20, 1995, August 22, 2001).

Beijing Review (September 18-24, 1995; October 16-22, 1995; March 13, 2000).

Bolewski, Wilfried and Candy M. Rietig, "The Cultural Impact on China's New Diplomacy," The Whitehead Journal of Diplomacy and International Relations, 9-2 (2008), pp.83-96.

Booth, Ken, Strategy and Ethnocentricism (New York: Holmes \& Meier, 1979).

Cheng, Joseph Y.S., "China's Japan Policy in the 1980s," International Affairs, 61-1 (1984/85), pp.91-107.

China News Agency (August 13, 2002; March 6, 2004).

Christensen, Thomas J., "China, the U.S.-Japan Alliance, and the Security Dilemma in East Asia," International Security, 23-4 (1999), 49-80.

Deng, Xiaoping, Selected Works of Deng Xiaoping, 1975-1982 (Beijing: Foreign Language Press, 1984).

Dirlik, Arif, "'Past Experience, If Not Forgotten, Is a Guide to the Future,' or, What Is in a Text? The Politics of History of China-Japan Relations," in Miyoshi Masao and H.D. Harootunian, eds., Japan in the World (Durham, NC: Duke University Press, 1993).

Donald, Munro J., "One-Minded Hierarchy Versus Interest-Group Pluralism: The Chinese Approaches to Conflict," in William Zimmerman and Harold K. Jacobson, eds., Behavior, Culture, and Conflict in World Politics (Ann Arbor: University of Michigan, 1993).

Downs, Anthony, An Economic Theory of Democracy (New York: Harper \& Row, 1957).

Drifte, Reinhard, “The End of Japan's ODA Yen Loan Programme to China in 2008 and Its Repercussions," Japan Aktuell, 16-1 (2008).

Elster, Jon, Nuts and Bolts for the Social Sciences (Cambridge: Cambridge University Press, 1989).

Furukawa, Mantaro, Nicchū sengo kankeishi nōto [A Memo of Post-War SinoJapanese Relations] (Tokyo: Sanseido, 1983).

—, Nicchū sengo kankei-shi [Post-War Sino-Japanese Relations] (Tokyo: Hara 
Shobō, 1981).

Gibbons, Michael, "Introduction: The Politics of Interpretation," in Michael Gibbons, ed., Interpreting Politics (New York: New York University Press, 1987).

Gray, Colin, Nuclear Strategy and National Style (Lanham, MD: Hamilton Press, 1986).

—, Modern Strategy (Oxford: Oxford University Press, 1999).

—, "Strategic Culture as Context: The First Generation of Theory Strikes Back," Review of International Studies, 25 (1999), pp.49-69.

Gries, Peter Hays, China's New Nationalism: Pride, Politics, and Diplomacy (Berkeley: University of California Press, 2004).

Halbwachs, Maurice, On Collective Memory, in Lewis A. Coser, ed. and trans. (Chicago: University of Chicago Press, 1992).

He, Yinan, The Search for Reconciliation: Sino-Japanese and German-Polish Relations since World War II (New York: Cambridge University Press, 2009).

Hofstede, Geert, "Diplomats as Cultural Bridge-builders," in Hannah Slavik, ed., International Communication and Diplomacy (Malta, Geneva: Diplofoundation, 2004), pp.25-38.

Hollander, Edward P., "Leadership and Power," in Gardner Lindzey and Elliot Aronson, eds., The Handbook of Social Psychology (New York: Random House, 1985).

Huang, Da-hui, Riben duihua zhengce yu guonei zhengzhi [Japan's China Policy and Its Domestic Politics] (Beijing: Dangdai Shijie Chubanshe, 2006).

Ijiri, Hidenori, "Sino-Japanese Controversy since the 1972 Diplomatic Normalization," in Christopher Howe, ed., China and Japan: History, Trends, and Prospects (Oxford: Clarendon Press, 1996).

Institute of Oriental Culture, University of Tokyo, "Nikka Heiwa Jōyaku" [SinoJapanese Peace Treaty] (1952), at http://www.ioc.u-tokyo.ac.jp/ worldjpn/ documents/texts/docs/19520428.T1J.html (searched date: November 23, 2010).

Jiang, Lifeng, "Zhongguo minzhong dui riben de buqinjingan xianzhu zengqiang" [The Evident Increase of Chinese Public Feeling of Alienation toward Japan] Riben Xuekan [Japanese Studies], 6 (2004).

Ji'nian Zhou Enlai Chuban Faxing Weiyuanhui [Publishing committee in memory of Zhou Enlai] ed, Ribenren xinmuzhong de Zhou Enlai [Zhou Enlai in the eyes of the Japanese] (Beijing: Zhonggong zhongyang dangxiao chuban, 1991).

Johnson, Chalmers, "The Pattern of Japanese Relations with China, 1952-1986," Pacific Affairs, 59-3 (1986), pp. 402-428.

Johnston, Iain Alastair, "Strategic Cultures Revisited: Reply to Colin Gray," Review of International Studies, 25 (1999), pp.519-23.

Katzenstein, Peter J., The Culture of National Security: Norms and Identity in 
World Politics (New York: Columbia University Press, 1996).

Kazankai, Nicchū kankei kihon shiryōshu [Basic Data of Japan-China Relations] (Tokyo: Kazankai, 1998).

Keddell, Joseph P., The Politics of Defense in Japan: Managing Internal and External Pressures (Armonk, NY: ME Sharpe, 1993).

Klein, Bradley, Strategic Studies and World Order: The Global Politics of Deterrence (Cambridge: Cambridge University Press, 1994).

Kobayashi, Yoshiki, "Chūgoku ni okeru tainichi kanjō ni kansuru kōsatsu" [A Study on Sentiments toward Japan in China], Ajia kenkyū [Asian Studies], 54-4 (2008), pp.87-108.

Laris, Michael, “An Apology Rooted in Fear,” Washington Post (25 November 1998).

Lock, Edward, "Refining Strategic Culture: Return of the Second Generation," Review of International Studies, 36 (2010), pp.685-708.

Lu, Jiantao, "A Social-Network Behavioural Approach to Overseas Chinese and Overseas Non-Chinese Investments in China," Tijdschrift voor Economische en Sociale Geografle, 4-7 (2012), pp.426-42.

Messick, David M., and Karen S. Cook, eds., Equity Theory: Psychological and Sociological Perspectives (New York: Praeger, 1983).

Ministry of Foreign Affairs of Japan, "Joint Communiqué of the Government of Japan and the Government of the People's Republic of China" (29 September 1972), at http://www.mofa.go.jp/region/asia-paci/china/joint72.html (searched date: 23 November 2010).

Ministry of Foreign Affairs of the People's Republic of China, "Some Sensitive Issues" (8 May 2002), at http://www.fmprc.gov.cn/eng/wjb/zzjg/yzs/ gjlb/2721/2722/t15974.htm (searched date: 23 November 2010).

Morgenthau, Hans J., In Defense of the National Interest (New York: Alfred A. Knopf, 1951).

Okada, Minoru, Nicchū kankei to ODA [Sino-Japanese Relations and ODA] (Tokyo: Nihon Kyohōsha, 2008).

People’s Daily (August 15-19, 1985; July 25-31, 2001; August 1, 3, 8, 10-18, 21, 23, 27, 2001).

Pye, Lucian, Chinese Commercial Negotiation Style (New York: Oelgeschlager, Gunn and Hain, 1982).

Qin, Ya-qing, "Guanxi benwei yu guocheng jiangou: jiang zhongguo linian zhiru guoji guanxi Lilun" [Relationship Orientation and Process Construction: Bringing Chinese Concepts into IR Theories] Zhongguo Shehui Kexue [Chinese Social Science], 3 (2009).

Rose, Caroline, Interpreting History in Sino-Japanese Relations: A Case Study in Political Decision-making (New York: Routledge, 1998). 
Ross, Robert, "U.S. Relations with China," in Ezra F. Vogel, Yuan Ming and Akihiko Tanaka, eds., The Golden Age of the U.S.-China-Japan Triangle, 19721989 (Cambridge: Harvard University Press, 2002).

Rousseau, David L., Identifying Threats and Threatening Identities (Stanford, CA: Stanford University Press, 2006)

Sapir, Edward, The Psychology of Culture: A Course of Lectures, Judith Irvine, ed. (The Hague: Mouton De Gruyter, 1993).

Schmitt, Carl, The Concept of the Political (New Brunswick: Rutgers and Littlefield, 1976).

Schueler, George F., Desire: Its Role in Practical Reason and the Explanation of Action (Cambridge: MIT Press, 1995).

Shinohara, Hiroshi, "Beichū sekkin to nihon no bōei," [Sino-U.S. Rapprochement and Japan's Defense] Chūō Kōron [Central Review] (October 1971).

Soeya, Yoshihide, “Japan's Relations with China,” in Ezra F. Vogel, Yuan Ming and Akihiko Tanaka, eds., The Golden Age (Cambridge: Harvard University Press: 2002).

Stein, Janice G., "Foreign Policy Decision-making," in Steve Smith, Amelia Hadfield and Tim Dunne, eds., Foreign Policy: Theories, Actors, Cases (New York: Oxford University Press, 2008).

Sun, Lung-kee, Zhongguo wenhua de“ shenceng jiegou” [The 'Deep Structure' of Chinese Culture] (Guilin: Guangxi Normal University, 2012).

Takeiri, Yoshikatsu, "Rekishi no haguruma ga mawatta" [The Cog of History Turned], in Akira Ishii, Jianrong Zhu, Yoshihide Soeya and Xiaoguang Lin, eds., Kiroku to kōshō: nicchū kokkō seijōka nicchū heiwa yūkō jōyaku teiketsu $k \bar{s} h \bar{o}$ [Documents and Investigations: Sino-Japanese Normalization and Japan-China Treaty of Peace and Amity Negotiations] (Tokyo: Iwanami Shoten, 2003).

Takeuchi, Yoshimi, Takeuchi Yoshimi zenshu [Yoshimi Takeuchi: Collected Works], 11 (Tokyo: Chikuma Shobō, 1981).

Tanaka, Akihiko, Nicchū kankei: 1945-1990 [Sino-Japanese Relations: 19451990] (Tokyo: Tokyo University, 1991).

Tian, Huan, ed., Zhanhou zhongri guanxi wenxianji [Documents of Post-War Sino-Japanese Relations], Volume 2: 1971-95 (Beijing: Zhongguo shehui kexue chubanshe, 1997).

Vogel, Ezra, "The United States Perspective," in Ezra F. Vogel, Yuan Ming and Akihiko Tanaka, eds., The Age of Uncertainty: The U.S.-China-Japan Triangle from Tiananmen (1989) to 9/11 (2001) (Cambridge, MA: Harvard University Asia Center, 2002).

Waltz, Kenneth, Theory of International Politics (New York: McGraw-Hill, 1979). Wan, Ming, Sino-Japanese Relations: Interaction, Logic and Transformation 
(Stanford, CA: Stanford University Press, 2006).

Wang, Zheng, "National Humiliation, History Education, and the Politics of Historical Memory: Patriotic Education Campaign in China," International Studies Quarterly, 52 (2008), pp.783-806.

Weber, Max, The Religion of China: Confucianism and Taoism (New York: Free Press, 1968).

-, "Objectivity in Social Science and Social Policy," in Edward Shils and Henry Finch, eds. and trans., The Methodology of Social Sciences (Glencoe, IL: Free Press, 1949), pp. 49-112.

Wendt, Alexander, "Anarchy is What States Make of It," International Organization, 46-2 (1992), pp.391-425.

-, Social Theory and International Politics (New York: Cambridge University Press, 1999).

Whiting, Allen S., China Eyes Japan (Berkeley: University of California Press, 1989).

Woshinsky, Oliver H., Culture and Politics: An Introduction to Mass and Elite Political Behavior (New Jersey: Prentice Hall, 1995).

Yan, Yunxiang, "The Culture of Guanxi in a North China Village," The China Journal, 35 (1996), pp.1-25.

Yanagida, Kunio, Nihon ha moeteiru ka [Is Japan Burning?] (Tokyo: Kōdansha, 1983).

Yang, Da-qing, "Nicchū ryōkoku no wakai" [Reconciliation of Japan and China], in Funabashi Yōichi, ed., Nihon no sensō sekinin wo dou kangaeru ka [How to Think about Japan's War Responsibility] (Tokyo: Asahi Shimbunsha, 2001).

Yang, Mayfair, "The Resilience of Guanxi and Its New Developments," The China Quarterly, 170 (2002), pp.459-76.

Yasuda, Jun, "Bōei yosanan 'tai GNP 1\% toppa' ni taisuru chūgoku gawa no hannō" [China's Reaction to the Defense Budget 'Over 1\% of GNP'] Shin Bōei Ronshu [Journal of National Defense], 15-1 (1987).

Yin, Yan-jun, Chünichi sensō baishō mondai [Sino-Japanese War Reparations Issues] (Tokyo: Ochanomizu Shobō, 1996).

Yomiuri Shimbun (June 23, 2001; November 27, 28, 1998).

Zhang, Jun-bo and Yao Yun-zhu, "Traditional Chinese Military Thinking," in Zhao Suisheng, ed., Chinese Foreign Policy (New York: East Gate Books, 2004).

Zhang, Shu-guang, "China: Traditional and Revolutionary Heritage," in Ken Booth and Russell Trood, eds., Strategic Cultures in the Asia-Pacific Region (London: Macmillan Press, 1999).

Zhang, Tuo-sheng, "China's Relations with Japan," in Ezra F. Vogel, Yuan Ming and Akihiko Tanaka, eds., The Golden Age (Cambridge: Harvard University Press, 2002). 


\section{About the Author}

Dr. Takeshi UEMURA is a research associate at the Waseda Institute of AsiaPacific Studies. His research focuses on Chinese culture's role in the PRC's foreign relations. His recent publication includes: "Chugoku bunka to gaikou seisaku” [Chinese Culture and Foreign Policy], Ajia Kenkyu [Asian Studies] 46 (4), 2010 .

Address: Centre for Global Discovery Bldg. 2, Sophia University Yotsuya Campus 7-1 Kioi-cho, Chiyada-ku, Tokyo 102-8854 Japan

Email: tuemura@sophia .ac.jp 